\title{
CHRONOLOGY OF THE TEXTS OF FRANCISCO HERNÁNDEZ
}

1566-67

$1570-77$

1580

1587

1590

1592

1597

1598
Hernández completes a large portion of his edition of Pliny, Natural History.

While in New Spain, Hernández finishes his edition of Pliny, composes the Antiquities of New Spain and Natural History of New Spain, writes The Christian Doctrine, and completes a large number of lesser works.

Philip II orders his physician, Nardo Antonio Recchi, to make a selection from Hernández's Natural History of New Spain. Hernández writes An Epistle to Arias Montano.

Hernández dies in Madrid.

In the second edition of Historia natural $y$ moral de las Indias (Barcelona), José Acosta gives a short account of Hernández's expedition to New Spain and the resulting manuscripts.

Fabio Colonna, Phytobasanos (Naples), mentions the description of tlapatl that had first appeared in the Hernández manuscripts and notes Recchi's work in progress.

Jaime Honorato Pomar commissions a volume of paintings of plants and animals, some copied directly from Hernández's originals.

A notarized copy of Hernández's Index medicamentorum, in Spanish, is made. The text is attributed to Gregorio López, with whose other work it is copied, and is acquired by Cardinal Riti.

1603 Federico Cesi, Duke of Aquasparta, founds the Accademia dei Lincei in Rome. Cesi acquires a manuscript copy of Recchi's selection of Hernández with the intention that it should be the new academy's leading publication.

1607 Juan Barrios, Verdadera medicina, cirugía y astrología (Mexico City) includes a different version, again in Spanish, of the Index medicamentorum.

1609 Barrios publishes a treatise on chocolate, in which he quotes Hernández and states that he owns a manuscript copy of Recchi's selection from the Natural History.

1614 Cesi proposes to Johannes Faber and Theodore Müller that they undertake a trip to Mexico to verify various aspects of the Recchi manuscript.

1615 Barrios's copy of Recchi's manuscript, translated into Spanish, is edited by Francisco Ximénez and published in Mexico City as the Quatro libros.

1616 Colonna's Minus cognitarum stirpium includes one chapter drawn in part from Recchi's manuscript.

1625-30 A director of the Dutch West India Company, Johannes de Laet, translates the text of the 
Quatro libros back into Latin. He may have had a manuscript copy first, then the printed book. Selections from his own Latin appear, translated again, in Dutch in Beschrijving van West-Indien (Leiden: Elsevier, 1630).

1628 Faber publishes Animalia mexicana descriptionibus scholiisque exposita, his annotated edition of Hernández's descriptions of Mexican animals. The Accademia dei Lincei apparently produces a prospectus for Hernández, Rerum medicarum Novae Hispaniae thesaurus, which will finally be published in 1651.

1633 De Laet expands his description of the New World, incorporates more selections from his translation of Hernández, and puts his Dutch text into Latin as Novus Orbis, published by Elsevier in Leiden.

1635 The Jesuit scholar Juan Eusebio Nieremberg includes 160 chapters from the Natural History and a substantial portion of the Antiquities in his Historia naturae, published by Moretus in Antwerp.

1640 De Laet's Latin text of 1633 is translated into French and published, again by Elsevier, in Leiden.

1648 De Laet edits the works on Brazilian botany and medicine by Willem Piso, De medicina Brasiliensi, and Georg Marcgraf, Historia rerum naturalium Brasiliae, published together in one volume (Leiden: Elsevier). Marcgraf (d. 1643) cites thirty-three descriptions from Hernández, supplied by de Laet.

1651 After half a century of perseverance, the Accademia dei Lincei finally publishes the large folio edition of Hernández, Rerum medicarum Novae Hispaniae thesaurus, with learned commentaries by the academicians.

1658 Piso brings out a second edition of his 1648 work, with several plagiarisms and unwarranted claims of authorship. He now includes a few texts by Hernández, taken from Marcgraf or de Laet.

1659 An English physician, Robert Lovell, includes the therapeutic information about ninety-five Mexican plants, taken from the Quatro libros or the Rome edition of Hernández (who is not acknowledged), in Pambotanologia, published in Oxford. A second edition comes out in 1665 .

1662 In The Indian Nectar, a treatise on chocolate, Henry Stubbe quotes from Hernández.

1685 John Chamberlayne cites Hernández as the principal authority on cacao in part of his translation of one of three tracts, together published as The Manner of Making of Coffee, Tea, and Chocolate.

1686 The first volume of John Ray's immense Historia plantarum uses Hernández as one of its many authorities. Volume 2 (1688) contains an appendix devoted solely to Hernández, consisting of a summary of the contents of the Rome edition, preceded by a brief introductory essay.

1687-88 Hans Sloane conducts botanical and medical research in Jamaica.

c. 1689 Another Englishman, James Newton, writes an herbal, which draws on six Hernández texts from the Rome edition, Marcgraf, and de Laet. Edited by his son, the work is published posthumously in 1752 .

1696 Abraham Munting, Naauwkeurige Beschrijving der Aardgewassen, devoted mainly to European plants, quotes briefly from the Rome edition and the Quatro libros in a few places. Sloane publishes an index of Jamaican plants, using Hernández as one of his many authorities.

c. 1690-1707 James Petiver, a London apothecary, annotates his copies of Nieremberg and Piso, with cross-references to Hernández.

1707 Sloane's Natural History of Jamaica, vol. 1, includes more than forty extracts from Hernández on Mexican plants.

1715 Petiver publishes a very short illustrated pamphlet in English that includes two descriptions of plants taken from Hernández.

1725 Sloane, Natural History of Jamaica, vol. 2, adds a few more selections from Hernández in English.

1752 James Newton's Enchyridion is published.

1766-72 Arnaud Vosmaer includes descriptions of the rattlesnake and bison, based on the Rome edition of Hernández and on Marcgraf and Nieremberg, in his book on exotic quadrupeds, birds, and snakes, Natuurkundige Beschrijving eener uitmuntende verzameling van zeldzame gedierten, bestaande in Oost-en Westindische viervoetige dieren, vogelen en slangen.

1790 The Opera of Hernández, vols. 1-3, edited by Casimiro Gómez Ortega, is printed by Joaquín Ibarra and published in Madrid.

1842 The first volume of the Colección de documentos inéditos para la historia de España, edited by Martín Fernández Navarrete, Miguel Salvá, and Pedro Sainz de Baranda, contains six letters from Hernández to King 
Philip II and one to Juan de Ovando, president of the Council of the Indies.

1888

1926 Two new editions of the Quatro libros: Antonio Peñafiel's is published in Mexico City, Nicolás León's in Morelia.

Facsimile reprint of the manuscript of Hernández's Antiquities (Mexico City).

1933 Maximino Martínez publishes Las plantas medicinales de México, dedicated to the memory of Hernández and relying on him for descriptions of seventy-one plants still used for medicinal purposes in Mexico.

$1942-45$

The Instituto de Biología de México produces a Spanish translation of the Madrid edition of 1790 .

1945 Joaquín García Pimentel produces a Spanish translation of the Antiquities (Mexico City).

1959-84 The Obras completas of Hernández appear in seven volumes, published by the Universidad Nacional Autónoma de México. 

THE MEXICAN TREASURY 
